\title{
Red blood cell alterations by in vitro action of Trichinella spiralis newborn larvae
}

\section{Patricia Ponce de León ${ }^{1 *}$, Martin Toderi² ${ }^{2}$ Horacio Castellini ${ }^{3}$ and Bibiana Riquelme ${ }^{4 *}$}

${ }^{1}$ Doctor in Biomedical Sciences, Facultad Cs, Bioquímicas y Farmacéuticas, Universidad Nacional de Rosario, Argentina

${ }^{2}$ Degree in Biotechnology, Facultad Cs, Bioquímicas y Farmacéuticas, Universidad Nacional de Rosario, Argentina

${ }^{3}$ Doctor in Physics, Facultad Cs, Exactas Ingeniería y Agrimensura, Universidad Nacional de Rosario, Argentina

${ }^{4}$ Doctor in Physics, Principal Researcher of the CIUNR, Facultad Cs, Bioquímicas y Farmacéuticas, Universidad Nacional de Rosario, Argentina

Received: 13 March, 2020

Accepted: 27 May, 2020

Published: 28 May, 2020

*Corresponding author: Patricia Ponce de León, Doctor in Biomedical Sciences, Facultad Cs, Bioquímicas y Farmacéuticas, Universidad Nacional de Rosario, Argentina, Tel: 5493416195215

E-mail: tefu1958@hotmail.com; pponcedeleon@fbioyf.unr.edu.ar

Keywords: Trichinella spiralis; Red blood cells; Erythrocyte viscoelasticity; Hemorheology

https://www.peertechz.com

\section{Check for updates}

\section{Abstract}

Background: $T$. spiralis establishes an intimate contact with the host erythrocytes during the newborn larvae migration through the bloodstream to their encystment in the muscle.

Objective: In the present work we study the alterations in the mechanical and aggregation properties of red blood cells produced in vitro by newborn larvae at low concentrations $(100,250,500$, and 1000 larvae/mL).

Methods: The study was performed by incubating human erythrocytes with an equal volume of different concentrations of newborn larvae for 30 minutes, with controlled agitation. To evaluate the erythrocyte alterations by the action of the larvae, the Erythrocyte Rheometer, the Optical Chip Aggregometer, and the Digital Image Analysis were used.

Results: In the treated erythrocyte samples, a decrease in isolated cell numbers and an increase in the aggregates were observed respect to the control at the higher larval concentration (1000 larvae/mL). The deformability index, the elastic modulus and surface viscosity showed no significant differences with the control; however, the storage modulus of the erythrocyte membrane decreased significantly with the increase in larval concentration. Erythrocyte aggregation parameters showed that the aggregation index increased with the larvae concentration present in the incubation, highlighting the presence of larger aggregates and clusters. The time to attain half of the maximum aggregation diminished, which implies faster aggregation kinetics.

Conclusion: The results observed in vitro describe the red blood cell alterations that could be produced during in vivo infection in the host.

\section{Introduction}

Trichinellosis is a major zoonosis in Latin America and represents a problem both to human and animal health [1]. Despite the high overall prevalence of intestinal worms in humans, and the economic impact they cause in the production of livestock, knowledge of the host-parasite relationship is still incomplete [2]. The biological cycle of Trichinella spiralis includes the migration of the new-born larvae (NBL) through the bloodstream, until its encystment in the muscle cell [3].

A key to understanding parasitic infections is the study of the interactions established between the two organisms involved: the host and the parasite.

The existence of more than 50 sialic acid structures is recognized, which are located at the end of the molecules 
of which they are part. Sialic acid present important biological functions, for it was deduced that some functions of glycoconjugates are determined, at least partially, by the participation of sialic acids in their composition. Their study has allowed us to consider that they will have an important role in the host-parasite relationship since the cellular mechanisms of many infectious processes would involve the surface glycoconjugates of both [4].

Kaneko and Anosa [5], communicated that a decrease in erythrocyte sialic acid alters the erythrocyte surface, modifying it antigenically and biochemically. These alterations could lead to increased phagocytosis of liver cells, contributing to the anemia status reported in this infection [6]. Moreover, erythrocyte desialylation can expose cryptic antigenic determinants of the membrane, among which is the $\mathrm{T}$ antigen It has been reported that $\mathrm{T}$ activation may occur in the stage of larvae circulating through the bloodstream (NBL), with consequent hemolysis, thrombocytopenia and thrombosis [7]. It is also important to study the possible hemorheological alterations produced in the host during infection to understand the parasite-host relationship that is established.

Red blood cells (RBC, erythrocytes) are the most abundant cells in the bloodstream and contain hemoglobin, the compound that carries oxygen through the body [8]. Due to their abundance and mechanical properties, RBCs are mainly responsible for blood rheological behavior influencing the blood viscosity, which depends on erythrocyte deformation and aggregation [9-11]. Sialic acid is responsible for the negative charge of the membrane of red blood cells. A decrease in surface electric charge promotes the erythrocyte aggregation leading to an increase in blood viscosity, which in turn induces an increase in flow resistance and could produce obstructions of microcapillaries, altering microcirculation [12-15].

Previous experiences reported that the contact of erythrocytes with $T$. spiralis larvae produces alterations in the erythrocyte aggregation [16-19].

In previous work, alterations in the viscoelastic and aggregation properties of human red blood cells by in vitro action of different concentrations of T. spiralis muscle larvae (ML) were studied [20]. NBLs have direct contact with the erythrocytes of the host during the migration, which could lead to hemorheological alterations affecting the microcirculation. Also, a study with high concentrations of newborn larvae (3000 $\mathrm{NBL} / \mathrm{mL}$ ) was carried out with 60 and 120 minute incubations, showing alterations in erythrocyte aggregation. However, at such larval concentrations, it was not possible to determine the erythrocyte viscoelastic parameters due to the formation of large erythrocyte aggregates that introduced noise in the signal [21]. Therefore, the aim of the present work was to study the alterations in the mechanical and aggregation properties of erythrocytes produced in vitro by lower concentrations of NBL after a $30 \mathrm{~min}$ incubation to avoid the interference of aggregates in the signal. The study was performed using techniques developed in our laboratory.

\section{Materials and methods}

\section{Newborn larvae T. spiralis}

Newborn larvae (NBL) were obtained from CBi mice infected with T. spiralis, which were provided by the animal research facility of the Experimental Genetics Institute (Faculty of Medical Sciences, National University of Rosario). CBi is an inbred mouse strain derived from an outbred population generated by crossing BALB/c, Rockland, NIH and Swiss mice. It was generated to be used as a base population of a broad genetic basis and as the control line of an experiment of artificial body conformation selection, which has given rise, among others, to $\mathrm{CBi}-$ and $\mathrm{CBi} / \mathrm{L}$ mice lines $[22,23]$.

Between 6 and 13 post-infection days, gravid females were obtained by surgery from the small intestine of mice. Females were incubated in a $100 \mu \mathrm{L}$ of RPMI-1640 medium (SigmaAldrich) supplemented with Gibco ${ }^{\mathrm{TM}}$ Fetal Bovine Serum and antibiotics for $18 \mathrm{~h}$ at $37^{\circ} \mathrm{C}$ in an atmosphere of $5 \% \mathrm{CO}_{2}$. NBLs were subsequently separated from adult females and collected in saline solution. Larvae concentrates were prepared at $24 \mathrm{~h}$, resulting in 100, 250, 500 and 1000 larvae/mL [24].

\section{Red blood cells}

Fresh group 0 blood samples were collected from healthy donors $(n=3)$ by venipuncture in sterile vials containing EDTA as anticoagulant, stored at $4^{\circ} \mathrm{C}$, and analyzed within 24 hours. The blood was centrifuged at $1,100 \mathrm{~g}\left(25^{\circ} \mathrm{C}, 5 \mathrm{~min}\right)$. After removing plasma and buffy-coat, RBCs were washed three times with saline solution (SS: $0.90 \% \mathrm{w} / \mathrm{v}$ of $\mathrm{NaCl}, 308$ $\mathrm{mOsm} / \mathrm{L}$ ). After the signature of the informed consent from participants, the collection and processing of samples were performed within $24 \mathrm{~h}$ from extraction time as recommended for hemorheological laboratory techniques [25]. This study has the approval of the Bioethical Committee of the Facultad de Cs. Bioquímicas y Farmacéuticas, Universidad Nacional de Rosario

\section{Erythrocyte treatment}

Treatment involves incubating $100 \mu \mathrm{L}$ of globular sediment with an equal volume of NBL concentrate (Treated RBCs). Control RBCs were incubated with saline solution (SS) in the same way. To evaluate the effect of NBL on erythrocyte aggregation, Treated and Control RBCs were incubated for 30 minutes at $37{ }^{\circ} \mathrm{C}$. Then, RBCs were washed in SS and resuspended in autologous plasma at $0.3 \%$ of hematocrit to obtain aggregation parameters by digital image analysis and at $40 \%$ of hematocrit to be measured in the optical chip. The erythrocyte treatment and hemorheological tests were carried out within $4 \mathrm{~h}$ after extraction.

\section{Erythrocyte aggregation by digital image analysis}

RBCs were suspended in autologous plasma (to induce rouleaux formation) at $0.3 \%$ hematocrit and poured into an excavated slide, which was placed on the stage of an Optical Inverted Microscope (Union Optical, Japan). After 5 minutes, aggregation of cells was attained and microscopic images of RBCs aggregate populations were registered by triplicate using

Citation: Ponce de Leon P, Toderi M, Castellini H, Riquelme B (2020) Red blood cell alterations by in vitro action of Trichinella spiralis newborn Larvae. Glob $J$ 
a 40x objective and a digital camera (Mikova DCM500 USB2.0) Each image was instantaneously stored in a computer file. Then, Image software was used to study alterations in erythrocyte aggregation by analyzing the distribution of aggregate size and by determining the Individual Cell Coefficient $\left(C_{C A}\right)[15,26]$. The $\mathrm{C}_{\mathrm{CA}}$ parameter was defined as:

$$
\mathrm{C}_{\mathrm{CA}}=\frac{\mathrm{CA}_{\text {nitial }}-\mathrm{CA}_{\text {final }}}{\mathrm{CA}_{\text {nitial }}}
$$

where $\mathrm{CA}_{\text {initial }}$ is the percentage of the individual cell number before larva treatment (Control) and $\mathrm{CA}_{\text {final }}$ is the individual cell percentage after larva treatment. This coefficient varies between 0 (no differences in aggregation before and after treatment) and 1 (complete aggregation after treatment).

A study of aggregate size distribution was also carried out. To do this, erythrocyte aggregates were counted and classified into four categories [27]:

- individual cells;

- $\quad$ aggregates of two and three cells;

- aggregates of four, five, and six cells;

- $\quad$ aggregates of 7 or more cells.

\section{Viscoelastic parameters of RBCs}

Data were obtained with the Erythrocyte Rheometer, which is an instrument developed in our laboratory based on laser diffractometry technique [28-30]. The following erythrocyte stationary and dynamic viscoelastic parameter corresponding to the oscillating shear stress at a cardiac frequency of 60 cycles per minutes $(1 \mathrm{~Hz})$ were determined $[9,10]$ :

DI: erythrocyte deformability index

$\boldsymbol{\mu}$ : elasticity of erythrocyte membrane

$\boldsymbol{\eta}$ : surface viscosity of erythrocyte membrane

G': storage modulus

G": loss modulus

In order to carry out these measurements, $100 \mu \mathrm{L}$ of each RBC sample in autologous plasma ( $40 \%$ hematocrit) was poured in $4.5 \mathrm{~mL}$ of a solution of polyvinylpyrrolidone (Sigma PVP360) at $5 \%(\mathrm{w} / \mathrm{v})$ in PBS (viscosity of $22.0 \mathrm{cp}, \mathrm{pH} 7.40$ and $295 \mathrm{mOsmol} / \mathrm{kg})$.

\section{Optical-chip aggregometer}

Erythrocyte aggregation kinetics was studied by an optical chip based on the analysis of light transmission through a blood sample recorded in real-time [31,32]. RBCs were suspended in autologous plasma at $40 \%$ hematocrit and $15 \mu \mathrm{L}$ of this suspension was used to assess erythrocyte aggregation within $400 \mathrm{~s}$. The optical chip is the physical support for the blood sample and consisted of a $5 \mathrm{~mm}$ diameter circular chamber of $15 \mu \mathrm{L}$ of volume. The measurement device sets the sample on a horizontal plane, and after disaggregation by mechanical agitation, a LED beam $(\lambda \sim 670 \mathrm{~nm})$ goes vertically through the sample and a photo-multiplier records variation in the incident light intensity. Graphics of light intensity as a function of time were obtained, and the aggregation parameters were used to calculate the following parameters:

AI: indicates the normalized amount of accumulated aggregation by calculating the integral of the registered curves.

$\mathbf{t}_{1 / 2}:$ the time required to reach half of the total transmitted light intensity at $400 \mathrm{~s}$, indicating a characteristic time constant for the average level of aggregation.

\section{Statistical analysis}

The mean and confidence interval were calculated in each blood sample measured in quintuplicate (control and treated with the different concentrations of $T$. spiralis newborn larvae). Then, $p$ values based on two-tailed statistical tests were calculated in each blood sample considering that in cases where $\mathrm{p}>0.05$, the difference is not significant [33].

\section{Results}

Examples of images of red blood cells untreated and treated with different concentrations of NBL are presented in Figure 1. A decrease in the number of isolated cells and an increase of the aggregates in the RBC treated were observed compared to the control, the most notable effect is when the concentration of NBL used in the treatment was higher. RBC untreated showed a large number of isolated cells and some small aggregates,

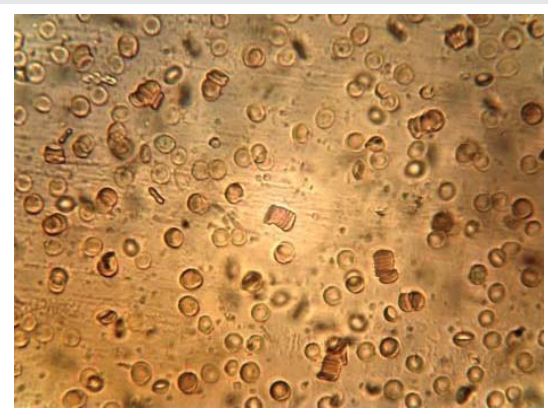

Figure 1a: Images obtained by microscopy of erythrocyte suspensions from: (a) Control

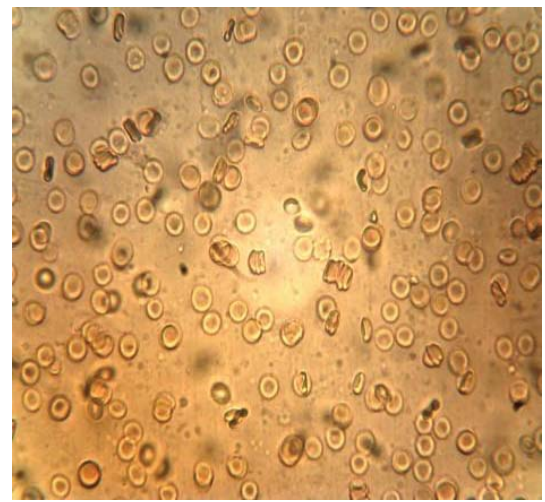

Figure 1b: Images obtained by microscopy of erythrocyte suspensions from: (b) RBCs treated with $(100 \pm 50)$ larvae $/ \mathrm{mL}$.

Citation: Ponce de Leon P, Toderi M, Castellini H, Riquelme B (2020) Red blood cell alterations by in vitro action of Trichinella spiralis newborn Larvae. Glob $J$ 
whereas large networks of erythrocytes were formed in the RBCs incubated with 1000 larvae/mL without morphological cell alterations.

All treated samples show significant alterations in $\mathrm{C}_{\mathrm{CA}}$ and aggregate size distribution respect to the control $(\mathrm{p}<0.001)$ as shown in Table 1 , where $C_{C A}$ values were higher with the increase in NBL concentration. The incubation with 100 larvae/ $\mathrm{mL}$ showed a $C_{C A}=0.31$, indicating that the aggregation was moderate, while in the treatment with 1000 larvae/mL the aggregation was very high $\left(C_{C A}=0.83\right)$.

The mean values of the erythrocyte viscoelastic parameters from RBC untreated and treated with NBL are shown in Table 2. Unlike the results obtained in previous work with $\mathrm{ML}$, in the case of NBL the deformability index and the elastic modulus

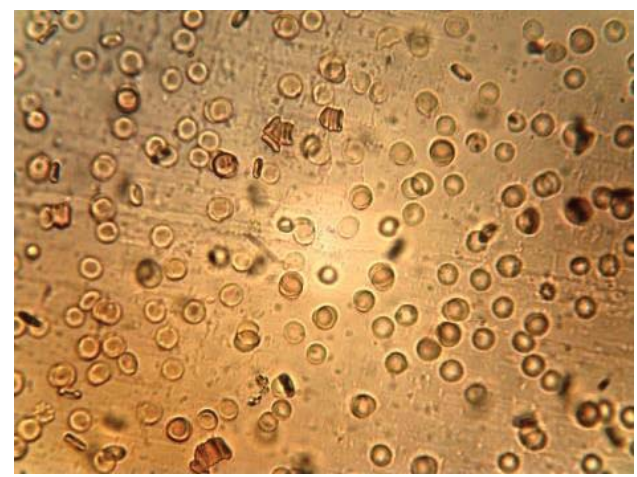

Figure 1c: Images obtained by microscopy of erythrocyte suspensions from: (c) RBCs treated with $(250 \pm 50)$ larvae/mL

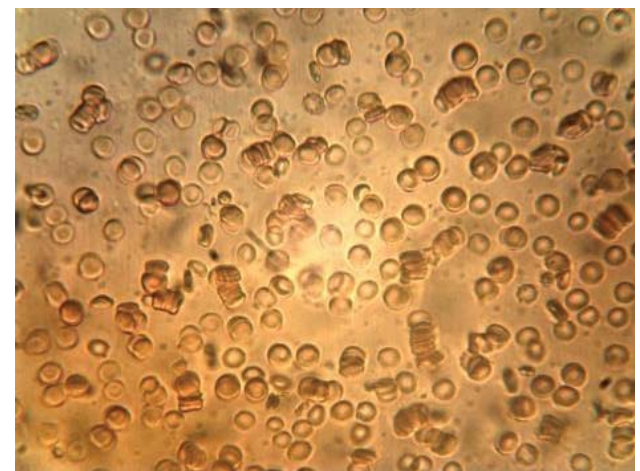

Figure 1d: Images obtained by microscopy of erythrocyte suspensions from: (d) RBCs treated with $(500 \pm 50)$ larvae/mL.

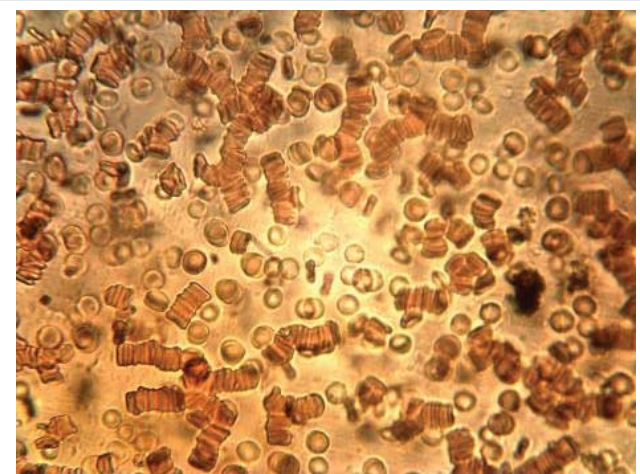

Figure 1e: Images obtained by microscopy of erythrocyte suspensions from: RBCs treated with $(1000 \pm 50)$ larvae/mL.
Table 1: Distribution of erythrocyte aggregate sizes and $C_{C A}$ values for each NBL concentration. Data shown are mean value \pm standard deviation from 3 blood samples measured in quintuplicate.

\begin{tabular}{|c|c|c|c|c|c|}
\hline $\begin{array}{c}\text { Cc } \\
\text { larvae/ } \\
\mathrm{mL}\end{array}$ & $\begin{array}{c}\text { Individual } \\
\text { cells }\end{array}$ & $\begin{array}{c}\text { Aggregates of } \\
\text { two and three } \\
\text { cells }\end{array}$ & $\begin{array}{c}\text { Aggregates of } \\
\text { four, five and six } \\
\text { cells }\end{array}$ & $\begin{array}{c}\text { Aggregates } \\
\text { of seven and } \\
\text { more cells }\end{array}$ & $\boldsymbol{C}_{\mathrm{CA}}$ \\
\hline 0 & $39.1 \pm 1.0$ & $20.4 \pm 1.6$ & $23.4 \pm 0.8$ & $16.9 \pm 1.7$ & 0 \\
\hline 100 & $27.2 \pm 1.7$ & $27.2 \pm 0.9$ & $26.8 \pm 1.2$ & $19.7 \pm 1.8$ & $0.31 \pm 0.02$ \\
\hline 250 & $20.5 \pm 1.5$ & $24.3 \pm 0.8$ & $16.8 \pm 1.7$ & $38.3 \pm 3.9$ & $0.46 \pm 0.03$ \\
\hline 500 & $16.1 \pm 1.8$ & $21.0 \pm 0.9$ & $16.6 \pm 1.3$ & $45.4 \pm 1.6$ & $0.59 \pm 0.04$ \\
\hline 1000 & $6.7 \pm 2.0$ & $6.8 \pm 0.9$ & $11.4 \pm 1.7$ & $74.9 \pm 2.8$ & $0.83 \pm 0.04$ \\
\hline
\end{tabular}

$p$-values from two-tailed statistical tests: $p<0.001$ for all parameters

Table 2: Stationary and dynamic viscoelastic parameters of erythrocytes for each NBL concentration. Data shown are mean value \pm standard deviation from 3 blood samples measured in quintuplicate.

\begin{tabular}{|c|c|c|c|c|c|}
\hline $\begin{array}{c}\text { Cc } \\
\text { larvae/mL }\end{array}$ & DI & $\underset{10^{-6} \mathrm{~N} / \mathrm{m}}{\mu}$ & $\begin{array}{c}\eta \\
10^{-7} \text { N.s } / \mathrm{m}\end{array}$ & $\begin{array}{c}\mathrm{G}^{\prime} \\
10^{-6} \mathrm{~N} / \mathrm{m}\end{array}$ & $\begin{array}{c}\mathrm{G}^{\prime \prime} \\
10^{-6} \mathrm{~N} / \mathrm{m}\end{array}$ \\
\hline 0 & $0.64 \pm 0.01$ & $5.09 \pm 0.01$ & $1.74 \pm 0.30$ & $4.73 \pm 0.09$ & $1.9 \pm 0.1$ \\
\hline 100 & $0.64 \pm 0.04$ & $4.98 \pm 0.08$ & $1.85 \pm 0.59$ & $4.62 \pm 0.08^{\star \star}$ & $1.9 \pm 0.1$ \\
\hline 250 & $0.69 \pm 0.05$ & $5.02 \pm 0.03$ & $1.75 \pm 0.30$ & $4.61 \pm 0.09 * *$ & $2.0 \pm 0.2$ \\
\hline 500 & $0.59 \pm 0.10$ & $5.02 \pm 0.04$ & $1.89 \pm 0.18^{*}$ & $4.59 \pm 0.08^{\star \star}$ & $2.0 \pm 0.2$ \\
\hline 1000 & $0.69 \pm 0.05$ & $5.10 \pm 0.06$ & $1.89 \pm 1.03$ & $4.69 \pm 0.10$ * & $2.0 \pm 0.2$ \\
\hline
\end{tabular}

$p$-values from two-tailed statistical intra-sample tests: ${ }^{*} \mathrm{p}<0.05 ;{ }^{* *} \mathrm{p}<0.001$

showed no significant alterations ( $\mathrm{p}>0.05$ ). As with ML treatment, an increase in the values of the surface viscosity of the membrane is observed in some measurements, but the averages did not show significant differences with the Control. Also, very high noise in the signal was observed at the higher concentration of larvae (1000 larvae/mL), probably due to the presence of micro-aggregates (as can be seen in the images of Figure 1), which interfere with the diffractometric readings of the Erythrocyte Rheometer. The storage modulus of the erythrocyte membrane (G') decreased significantly with the larvae concentration in the treated samples $(\mathrm{p}<0.001)$.

Erythrocyte aggregation parameters presented in Table 3 show that the AI increased with the number of larvae per $\mathrm{mL}$ present in the incubation process. This result evidences the presence of larger and more globular aggregates, while $t_{1 / 2}$ diminished, which implies faster aggregation kinetics. A higher concentration of larvae in the incubation presents kinetic curves with greater slopes at the beginning of the phenomenon, which gives shorter $t_{1 / 2}$. This could be attributed to a decrease in the surface charge of the cells, favoring the formation of aggregates due to decreased electrostatic repulsion among erythrocytes. Also, it contributes to the formation of globular aggregates, which allows greater transmission of light through the blood sample.

\section{Discussion}

Previous work with ML [20], showed a change in the viscoelastic and aggregation properties of the erythrocyte membrane, suggesting that the greater erythrocyte alteration by the action of the larvae occurs in the cytoskeleton and glycocalyx. Besides, in other parasitoses such as Trypanosoma cruzi [34] and Ascaris lumbricoides [15], the authors suggested 
Table 3: Aggregation parameters of erythrocytes for each NBL concentration. Data shown are mean value \pm standard deviation from 3 blood samples measured.

\begin{tabular}{|c|c|c|}
\hline $\begin{array}{c}\text { Cc } \\
\text { larvae/mL }\end{array}$ & $\begin{array}{c}\mathbf{t}_{1 / 2} \\
\mathbf{s}\end{array}$ & Al \\
\hline 0 & $88 \pm 2$ & $0.67 \pm 0.02$ \\
\hline 100 & $87 \pm 2$ & $0.68 \pm 0.02$ \\
\hline 250 & $80 \pm 2$ & $0.70 \pm 0.01$ \\
\hline 500 & $48 \pm 2$ & $0.77 \pm 0.02$ \\
\hline 1000 & $47 \pm 2$ & $0.78 \pm 0.01$ \\
\hline
\end{tabular}

that these alterations could be associated with the capture of erythrocyte sialic acid by parasite.

In the present work, the results from aggregation parameters of treated samples with new-born larvae showed significant alterations respect to the control. This result is similar to what was observed in the incubation with muscle larvae [20], but a little less pronounced. Also, results showed that the erythrocyte aggregation is higher when the larval concentration used increased, which translates into a decrease in the number of individual cells and the formation of larger erythrocyte aggregates. The incubation with 1000 larvae/ml showed a $\mathrm{C}_{\mathrm{CA}}$ value of 0.83 , indicating the formation of larger erythrocyte aggregates as compared to the control but smaller than those obtained with muscle larvae. This observed increase in aggregation suggests a decrease in the erythrocyte surface electric charge, similar to reported in other work by P. Ponce de León, et al. $[16,17]$. According to experiments using the Polybrene immune-hematological test, these alterations in the electric charge could be due to a decrease in sialic acid on the membrane $[18,35]$.

The deformability index and the elastic modulus showed no significant alterations, but storage modulus ( $G^{\prime}$ ) decreased significantly with the larvae concentration in the treated samples $(p<0.05)$. This relevant result would indicate that the cytoskeleton of erythrocyte may become softer due to the interaction with the NBL.

Results show that $t_{1 / 2}$ diminished, indicating faster aggregation kinetics probably related to an alteration in the surface electric charge produced by the action of new-born larvae, as was shown in previous work [21].

Previous work demonstrates that newborn larvae produce alterations in the erythrocyte aggregation [21]. Now, results confirm that the new-born larvae also induce alterations in the viscoelastic properties of the erythrocyte membrane. These results complete the hemorheological evaluation of action de new-born larvae.

Although studies have been carried out on muscle larvae of Trichinella spiralis, the importance of this study with newborn larvae lies in the fact that they circulate through the blood so that the erythrocyte alterations that they produce are of biomedical relevance.

\section{Conclusion}

Our investigation group has studied the trichinellosis applying immune-hematological $[7,18,32]$, hemorheological [16,19-21], and physical-mathematical [36-38] techniques. The importance of this type of researches is that the interdisciplinary study enriches the knowledge of the parasite-host relationship and the clinical implications of this parasitosis.

The results observed in vitro with new-born larvae Trichinella spiralis suggest that hemorheological alterations in the host could be produced during in vivo infection.

\section{Declarations}

\section{Funding}

This study was carried out with the financial support of Universidad Nacional de Rosario.

\section{Ethics approval (include appropriate approvals or wai- vers)}

This study is part of the research project entitled "Effect of Trichinella spiralis on erythrocyte desialization. Part II" was approved (Resolution CD 826/2018) by the Ethics Committee of the Faculty of Biochemical and Pharmaceutical Sciences of the National University of Rosario, which has elaborated the "Ethics in the treatment of scientific information data" document (Resolution CD 337/2015;

(https://www.fbioyf.unr.edu.ar/evirtual/pluginfile. $\mathrm{php} / 174802 / \mathrm{mod}$ resource/content/1/DOCUMENTO\%20 DE\%20CEUNR\%20Pag1-3.pdf) and CICUAL Rules of Procedure (Resolution CD 283/2016;

https://www.fbioyf.unr.edu.ar/evirtual/pluginfile. php/174796/mod_resource/content/1/16CD283.RES.pdf).

\section{Consent to participate (include appropriate statements)}

All participants must sign the informed consent in accordance with the regulations of the Facultad de Ciencias Bioquímcias y Farmacéuticas (UNR).

\section{Acknowledgments}

The authors thank the Universidad Nacional de Rosario for financial support. We would also like to extend our gratitude to Doctor Maria Delia Vasconi and Bioq. Mariana Bellini for their significant collaboration in the sample preparation and experiments. We would like to thank the staff from the English Department of the Facultad de Ciencias Bioquímicas y Farmacéuticas (UNR) for the language correction of the manuscript.

\section{References}

1. Pozio E, Zarlenga DS (2005) Recent advances on the taxonomy, systematics and epidemiology of Trichinella. Int J Parasitol 35: 1191-1204. Link: https://bit.ly/2A7oUcN

2. Nino Incani R, Morales G, Cesari IM (2001) Parasite and vertebrate host genetic heterogeneity determine the outcome of infection by Schistosoma mansoni, Parasitology Research 87: 131-137. Link: https://bit.ly/2M4NOHX

3. Ribicich M, Gamble HR, Rosa A, Bolpe J, Franco A (2005) Trichinellosis in Argentina: An historical review. Veterinary Parasitology 132: 137-142. Link: https://bit.ly/2LZjdAr

4. Cabezas Fernández del Campo JA (2008) Influencia de la sialilación y de la 
"pegilación" de la molécula de ciertos medicamentos en su actividad. An R Acad Nac Farm 74: 409-429. Link: https://bit.ly/2XzEXYT

5. Anosa VO, Kaneko JJ (1983) Pathogenesis of Trypanosoma brucei infection in deer mice (Peromyscus maniculatus): Light and Electron Microscopic Studies on Erythrocyte Pathologic Changes and Phagocytosis. Am J Vet Res 44: 645-651. Link: https://bit.ly/2X8AxJH

6. Masao K, Yuzaburo O, Shin-ichiro F, Hong-Kean O (1983) Preliminary observation on the absence of globule leucocytes in mast cell deficient anemic mice after Trichinella spiralis infection. JPN J Vet Res 31: 133-140. Link: https://bit.ly/3erjlVE

7. Ponce de León P, Nocelli J, López Murúa G (2017) Exposición de criptoantígeno eritrocitario por larvas recién nacidas de Trichinella spiralis. Acta Bioquím Clín Latinoam 51: 669-673. Link: https://bit.ly/2TKgsal

8. Cho S, Namgung B, Kim HS, Leo HL, Kim S (2015) Effect of erythrocyte aggregation at pathological levels on NO/O2 transport in small arterioles. Clin Hemorheol Microcirc 59: 163-175. Link: https://bit.ly/2AXWmmn

9. Riquelme B, Valverde J, Rasia RJ (1986) Complex viscoelasticity of normal and lectin treated erythrocyte using laser diffractometry. Biorheology 35: 325 334. Link: https://bit.ly/3dj9Wzj

10. Riquelme B, Valverde J, Rasia RJ (1999) Optical method to determine the complex viscoelasticity parameters of human red blood cells. In Medical Diagnostic Techniques and Procedures. Megha Singh et al. (eds), New Delhi Narosa Publishing House 249-255.

11. Rampling MW, Meiselman HJ, Neu B, Baskurt OK (2004) Influence of cellspecific factors on red blood cell aggregation. Biorheology 41: 91-112. Link: https://bit.ly/2yAq00c

12. Chien S, Sung LA (1987) Physicochemical basis and clinical implications of red cell aggregation. Clinical Hemorheology 7: 71-91. Link: https://bit.ly/2ZHqAEw

13. Jung F, Mrowietz C, Hiebl B, Franke RP, Pindur G, et al. (2011) Influence of rheological parameters on the velocity of erythrocytes passing nailfold capillaries in humans. Clin Hemorheol Microcirc 48: 129-139. Link: https://bit.ly/2LZnsMn

14. Kaliviotis E, Ivanov I, Antonova N, Yianneskis M (2010) Erythrocyte aggregation at non-steady flow conditions: A comparison of characteristics measured with electrorheology and image analysis. Clin Hemorheol Microcirc 44: 43-54. Link: https://bit.ly/2TI7bj4

15. Ponce de León $P$, Juárez Matamoros K, Biondi C, Valverde J (2011) Alteration in superficial anionic charge of erythrocytes and desialated erythrocytes caused by Ascaris lumbricoides. Rev Cubana Med Trop 63: 87-90. Link: https://bit.ly/2B6GwGi

16. Ponce de León $P$, López Murúa G, Bertorini G, Vasconi MD, Riquelme B (2013) Efecto biorreológico de larvas de Trichinella spiralis sobre la agregación eritrocitaria mediante Análisis Digital de Imágenes. In Ciencia y Tecnología Rosario: UNR Editora 268

17. Ponce de León P, Fernández A, Racca L, Vasconi MD (2015) Alteración de la agregación eritrocitaria por larvas recién nacidas de Trichinella spiralis. Acta Bioquím Clín Latinoam 49: 417-423. Link: https://bit.ly/3c8rOew

18. López Murúa G, Racca L, Ponce de León P (2014) Efecto de Trichinella spiralis sobre la cinética de agregación eritrocitaria. In Ciencia y Tecnología. Rosario: UNR Editora 61-63.

19. Ponce de León $P$, López Murúa G, Racca L (2017) Análisis digital de imágenes: Estudio de la agregación eritrocitaria por larvas infectantes de Trichinella spiralis. In Ciencia y Tecnología. Rosario: UNR Editora 210-215.

20. Ponce de León P, Bellini M, Castellini H, Riquelme B (2018) Alterations of the erythrocyte membrane by in vitro action of Trichinella spiralis muscle larvae. J Helminthol 94: e17. Link: https://bit.ly/2B6LfYx

21. Ponce de León $P$, Toderi $M$, Castellini $H$, Riquelme $B$ (2017) In vitro alterations of erythrocyte aggregation by action of Trichinella spiralis newborn larvae. Clinical Hemorheology and Microcirculation 65: 195-204. Link: https://bit.ly/2zARLGn

22. Di Masso RJ, Abdala SB, Sánchez SM, Font MT (1991) Respuesta a la selección divergente por conformación corporal en el ratón. Mendeliana 9: 79-92.

23. Hinrichsen L, Di Masso RJ (2010) Empleo de un modelo murino original de Argentina en la caracterización de fenotipos complejos. Journal of Basic and Applied Genetics 21: 1-12. Link: https://bit.ly/3d8qp98

24. Luebke RW (2007) Nematodes as host resistance models for detection of immunotoxicity. Methods 41: 38-47. Link: https://bit.ly/2X4Bken

25. Baskurt OK, Hardeman MR, Rampling MW, Meiselman HJ (2007) Handbook of Hemorheology and Hemodynamics. $1^{\text {a }}$ ed. Amsterdam, IOS Press. Link: https://bit.ly/2X3R29C

26. Riquelme B, Alet A, Basso S, Delannoy M, Alet N, et al (2015) Innovative parameters obtained for digital analysis of microscopic images to evaluate in vitro hemorheological action of anesthetics. In Biophotonics South America, USA, SPIE. Link: https://bit.ly/36xmCzM

27. Fontana A, Lerda N, Delannoy M, Riquelme B (2012) Técnica de cuantificación de la agregación eritrocitaria por análisis digital de imágenes. Acta Bioq Clín latinoamer 46: 47-52. Link: https://bit.ly/2TFOTiA

28. Albea B, Marenzana A, Castellini H, Riquelme B (2013) New instrument for easy determination of rheological parameters of erythrocytes. Biochimica Clinica 37: $\$ 437$

29. Riquelme B, Brenda A, Marenzana A, Castellini H (2013) Reómetro Eritrocitario. Invention Patent AR 091467 A1. Link: https://bit.ly/3elmhCY

30. Riquelme B, Castellini H, Albea B (2018) Linear and Non-linear Viscoelasticity of Red Blood Cells using a New Optical Erythrocyte Rheometer. In Latin America Optics and Photonics Conference, OSA Technical Digest, paper Th4A.41. Link: https://bit.ly/2TJtuF8

31. Toderi MA, Castellini $H$, Riquelme B (2015) Simplified variant of an optica chip to evaluate aggregation of red blood cells. Proceeding SPIE 9531. Link: https://bit.ly/2XySy2z

32. Toderi MA, Castellini H, Riquelme B (2017) Descriptive parameters of the erythrocyte aggregation phenomenon using a laser transmission optical chip. J Biomed Opt 22: 17003. Link: https://bit.ly/3grgwFA

33. Devore J (2013) Probabilidad y estadística para ingeniería y ciencias ( $7^{\circ} \mathrm{ed}$.) México, Editorial Latinoamericana.

34. Souto- Padron T (2002) The surface charge of trypanosomatids. Anais da Academia Brasileira de Ciências 74: 649-675. Link: https://bit.ly/2zzFVwm

35. Ponce de León P, López Murúa G, Racca L (2015) Estudio del efecto de Trichinella spiralis sobre la desialización aplicando el Método de Polibrene. Acta Bioquím Clín latinoam 49: 347-352. Link: https://bit.ly/3ddbUkl

36. Mancilla Canales M, Martínez A, Ponce de León P, Korol A (2015) Evaluation of fractal dimensión of human erythrocites incubated with Trichinella spiralis larvae in vitro. Biocell 39: A8.

37. Leguto AJ, Rebechi JP, Mancilla Canales MA, Ponce de León P, Bortolato SA, et al. (2018) Development of a simple methodology base on fractal mathematics por selective diagnosis of red blood cells disorders. Mecánica Computacional 36: 441-447. Link: https://bit.ly/2zAVqnB

38. Ponce de León P, Korol A (2016) Método de matemática no lineal aplicado al estudio de la desialisación producida por larvas musculares de Trichinella spiralis. In Ciencia y Tecnología. Rosario: UNR Editora 263-271.

Copyright: (c) 2020 Ponce de Leon P, et al. This is an open-access article distributed under the terms of the Creative Commons Attribution License, which permits unrestricted use, distribution, and reproduction in any medium, provided the original author and source are credited.

Citation: De León PP, Toderi M, Castellini H, Riquelme B (2020) Red Blood Cell Alterations by in Vitro Action of Trichinella spiralis Newborn Larvae. Glob J Biotechnol Biomater Sci 6(1): 007-012. DOI: https://dx.doi.org/10.17352/gjbbs.000012 